\title{
DEPRESSED HOUSEWIVES AS RESULTS OF WOMAN-OPPRESSION FOUND IN SHORT-STORIES: A COMPARATIVE LITERATURE STUDY
}

\author{
Fransiska Marsela \\ fransiskamarsela@gmail.com
}

\begin{abstract}
Literature represents and portrays variation of society and all human life's aspects. This includes common happenings. On behalf of this matter, there is an importance to study the literature as a model of real life and society, followed by certain phenomena happened in certain time. For ages, oppression and depression are one of frequents phenomena. Oppressions are often found in women, especially in housewives. This may lead to implication that housewives may undergo psychological problem, such as depression. In literary work, both woman-oppression and depression are often found in many kinds of works, such as movie and short-story. This research focused on two short-stories written by Thomas Hardy "An Imaginative Woman" (1893) and Jhumpa Lahiri "Interpreter of Maladies" (1999). Both were analyzed using feminism and psychoanalysis approach in terms of proving the hypothesis that woman-oppression can become source of depression in housewives' lives. The findings showed that domestic women, especially those who only work as housewives experienced depression because of their lack of social-connection. In both short-stories, the depressed housewives would lead her life into troublesome habits, such as having delusions, having affair beyond marriage, being ignorant toward her family, being in destructive behaviors, and even wishing her own death. This findings surely became an implication that women-oppression will indeed lead women into self-destructing behaviors.
\end{abstract}

\section{Introduction}

Peterson (1992) states that Freud - the founder of psychoanalysis theory - conveys "If by understanding human psychology..., we can appreciate literature into new level, then we should acquaint ourselves with this insight". Based on Freud's statement, there is an implication that literature depicts variation of reality. This is also supported by Wellek and Warren (1977) who state that literature mirrors and expresses life. Literature possesses ambiguous characteristics which means that literature is born from the events happen in the society, and at the same time, literature may influence society itself. 
Basically, an approach of literature study is divided into two types: the intrinsic approach and the extrinsic approach. Wellek and Warren (1977) introduced intrinsic approach, which essentially is a study of literary work based on analyzing the internal elements that build that work. There are several intrinsic elements, but ones which bear important connection with real life are characters and settings. According to Abrams (1971) character is "They are people who present in dramatic or narrative works" and a major character means that a figure of person who is mostly talked about in the story.

In complementing characters, setting as intrinsic element, helps to elaborate, describe or underline certain aspects of action of the characters that occur. In agreemen witt this, Potter (1967) explain how setting and characters intertwine in certain literary work, "Obviously, the actions of the characters take place at some time, in some place, amid some things; these temporal and spatial surroundings are the setting. The setting may be slight, vague, and sparsely detailed, or full and sharply detailed, but in either case it can be verisimilitude it can lend to the story, and the positive contribution it can make to its nature and effect (Potter, 1967)"

From the description above, there is a clear implication that setting and characters always relate to social life, and therefore they become an intrinsic element which relates firmly to the extrinsic elements, such as the period when certain work is created or the biography of author which implies the cultural and situational context when work or prose is created. The context here related to social setting which includes time and place setting all aspects in the story.

Since setting and characters are important elements which imply the social condition, then literature can serve as model of real life in certain age and or certain area. The character represents the life of real people and the setting represents the cultural-situational context in certain period or place. Thus, literature can become a source of sociological and psychological analysis.

Due to implication that literary work is a reflection of society and its tendency to portray sociological and psychological phenomena, then the writer conducted a research focused on women-oppression as sociological phenomena and depression as psychological 
phenomena. As object of analysis, the writer focused on investigating both phenomena in two short-stories. Two short-stories are taken from two authors. The first short story was Intepreter of Maladies (1999) written by Jhumpa Lahiri and the second short story was An Imaginative Woman (1893) written by Thomas Hardy.

\section{Theoretical Framework}

\section{Feminism in literary work}

Since the study focused on women-oppression and depression, then there is a necessity to enclose detail theories that pioneering the term of 'woman-oppression'. The theory which becomes the base of investigating woman-oppression is feminism. Feminism is built on the conception of gender-inequality. Therefore, the theoretical framework would be started by describing the concept of gender-inequality through the work of several scholars.

Hollander (2002) states that gender is a social construction, not something related to biological differences or biological distinction. Most scholars agree that gender is socially constructed. There is an invisible agreement which later develops into certain ideology that constructs the dominant hegemonic society. This ideology is humanly created, so it allows a room for change and can be seen as hegemonic dynamic which takes place as an abstract phenomenon. It means that one cannot really see how it takes place without feeling it. It can be traced by one who has witnessed many years of differences in human behavior over decades. Therefore, there is actual need to observe the result of this phenomenon in women as the side who are seen lower than men.

The conception of gender-inequality was followed by woman movement - the base of the feminism. Evolving throughout the nineteenth century, the Woman Movement developed in response to women's dependent situation. During the 1820s, 1830s, and 1840s, the nonproductive matron became a symbol of "bourgeois class hegemony" through an ideal now known as the "Cult of True Womanhood." This ideal "prescribed a female role bound by kitchen and nursery, overlaid with piety and purity, and crowned with subservience". "True Woman" was designated as the symbolic keeper of morality and decency within the home, being regarded as innately superior to men when it came to women 
virtues: "Piety, purity, submissiveness, and domesticity" were thought to be natural for women in $18^{\text {th }}-19^{\text {th }}$ century (Cruea, 2005).

The movement of feminism as described before had opened more opportunities for women. The idea that a woman must serve as an "angel in the house" gradually subdued, and the virtues of women had developed to the direction of equality with men. However, It is elaborated (Katz et all, 2005) that inequality is an idea with multiple dimensions. Its relations with sex, or for that matter, with race, ethnicity, or age, require examination from different vantage points - a point not appreciated or observed in most analyses of inequality. Many kinds of inequality - in domestic, social, and political spheres-have shaped women's experiences for generations. And thus even women in the $20^{\text {th }}$ century had gained more rights in many life spheres, including law and political spheres; nevertheless the inequality and gender paradigm still lurks as a paradox behind both men and women daily life. The easiest example is the form of behavioral pattern.

The thought that woman task is all in domestic sphere still becomes a 'daily phenomenon' although women have gained more rights to life their own life. This inequality acts like an unseen oppressor, more than the real man does. There are more examples of inequalities which have been curved in history of $20^{\text {th }}$ century, especially the ones related to job and economic status of women. The historical record is clearer about how exploitation and opportunity hoarding shaped women's inequality in the twentieth-century than it is about the role of emulation and adaptation.

Underlining the statements of Katz et. all (2005), exploitation took various forms, there is some forms of woman-exploitation. Exploitation can be found as rules that prohibited the employment of married women, actions by labor unions concerned with preserving male family wages, and hegemonic cultural ideas that assigned married women to domestic labor while devaluing the kinds of market work they performed, to name three that were particularly important. Opportunity blocking refers to the creation of occupational niches by and for women.

The message of the women's movement, as interpreted by some of those outside it, is not just that women should have equality of power and status with men; it is a questioning 
of all such power and status. It is not that the world will be better off with more female participation in it; it is that without the 'feminization' of human history, the world is unlikely to survive. In line with the history of feminism, Mackinnon (1982) explains that feminism is established as social-construction, universal movement, yet historically specific, as a join composition of matter and mind. Heterosexuality is the structure of feminism and control becomes the issue of feminism.

\section{Psychoanalysis and Depression}

Depression is a mood disorder which prevents individuals from leading a normal life, at work socially or within their family. Seligman (1973) states that depression is the 'common cold' of psychiatry due to its frequent diagnosis.

Social-inactiveness is common among depressed individual. Aside of that depression can happen because of careless reinforcement of depressed attitude by others. For instance, when someone lost a dear person, a crucial source of positive reinforcement has also lost. This loss may stimulates inactivity. Therefore, the main source of reinforcement is now the sympathy and attention of friends and relatives.

Nevertheless this may also stimulate malefic behavior, such as weeping, complaining, and talking of suicide. This gradually eliminates even close friends which pushes someone to even less reinforcement, increasing social isolation and unhappiness. In other words depression is a vicious cycle in which the person is driven further and further down. In addition, if the person lacks social skills or has complex personality structure, they may have obstacles to make necessary steps to seek new and alternative sources of reinforcement (Lewinsohn, 1974). The lack of solution and reinforcement may pushed down the depressed people into further unresolved negativity.

Freud's psychoanalytic theory is an example of the psychodynamic approach. Freud (1917) stated that many cases of depression were due to biological factors. However, Freud also argued that depression may relate to loss or rejection by a parent. Depression is similar with grief, in that it often occurs as a reaction to the loss of an important relationship. 
However, there is an important difference, because depressed people regard themselves as worthless. In depression case, the patient identifies oneself with the lost person, so that repressed anger towards the lost person is directed inwards towards the self. The inner directed anger reduces the individual's self-esteem, and makes him/her vulnerable to experiencing depression in the future.

Freud distinguished between actual losses (e.g. death of a loved one) and symbolic losses (e.g. loss of a job). Both kinds of losses can produce depression by causing the individual to re-experience childhood episodes when they experienced loss of affection from some significant person (e.g. a parent). Later, Freud modified his theory stating that the tendency to internalize loss objects is normal, and that depression is simply due to an excessively severe super-ego. Thus, the depressive phase occurs when the individual's superego or conscience is dominant. In contrast, the manic phase occurs when the individual's ego or rational mind asserts itself, and s/he feels control.

In order to avoid loss turning into depression, the individual needs to engage in a period of mourning work, during which s/he recalls memories of the lost one. This allows the individual to separate him/herself from the lost person, and so reduce the inner-directed anger. However, individuals very dependent on others for their sense of self-esteem may be unable to do this, and so remain extremely depressed.

Following the background and theoretical framework explained above, thus this study is intended to observe and elaborate woman-oppression as social phenomena along with its result, woman-depression as psychological phenomena. The study focused on two female characters from two short-stories. Both characters are housewives which experienced depression in their marriage life.

\section{Research Method}

The analysis used in this study is a qualitative analysis. It is used to describe a research by applying theories related to the subject matter. The qualitative analysis is a procedure of investigation, which result in descriptive data namely writing or spoken words and observable attitudes. This analysis is used for describing female characters' behaviors, 
utterances, and actions which can be the result of women oppressions. In this study, depression became the main phenomena which was stressed hypothetically as the effect of women oppression.

Sociological and psychoanalytic approach are applied as an approach in elaborating feminism theory and women oppression which is the centre of feminism itself. These approaches were applied in analysing and elaborating intrinsic elements of several chosen short stories, namely character and setting.

\section{Findings and Discussion}

Throughout some centuries, woman oppression has come from society via certain mechanism. As stated by Cruea (2005) that the mechanism is usually found in the form of belief toward certain role model of woman. For example, in the $19^{\text {th }}$ century, there was a belief which was described as 'cardinal virtue' which standardized women in submissive fashion. Barbara Welter stated this in Dimity Convictions: The American Woman in the Nineteenth Century (1976), a "True Woman" was designated as the symbolic keeper of morality and decency within the home, being regarded as innately superior to men when it came to women virtues: Piety, purity, submissiveness, and domesticity.

Nevertheless, the idea that woman is obliged to marry certain man, and live her life domestically, can become such psychological burden for woman. This may happen when the marriage happens without earnest concern, such as in a marriage which happens based on familial agreement. In Interpreter of Maladies (Lahiri, 1999), the main female character named Mrs. Das, experiences the psychological burden due to such marriage. How Mrs. Das, as a young housewife is afflicted by marriage and burdened by her domestic tasks, can be found in the following quotations.

We married when we were in college...our parents were best friends lived in the same town...I think it was all more or less a setup.

After marrying so young she was overwhelmed by having child so quickly and nursing, while her husband was at work..., her husband never looked cross or harried or plump as she had become after the first baby.

Always tired, she declined invitations from her one or two college girlfriends, to have lunch or shop in Manhattan. Eventually the friends stopped calling her, so that 
she was left at home all day with the baby, surrounded by toys that made her trip when she walked or wince when she sat, always cross and tired.

As a result of spending all her time in college with Raj, she did not make many close friends. There was no one to confide in about him at the end of a difficult day, or to share a passing thought or a worry.

After analyzing aforementioned quotation, there is obvious evident that Mrs. Das does not make any friendships because of her early marriage. Additionally, the physical condition of Mrs. Das is also afflicted by nursing baby without the help of her husband. Therefore, after she gets married, she is forced to take care of every single domestic job, while her husband never looks tired at all. The previous quotation is a great evidence to show that there are continuous domestic burdens that a woman has to bear, without the help of her husband, even both had been united in marriage. While a husband does not experience any alienation after marriage, a wife, especially a housewife may experience alienation due to her tasks of caring toward children and household.

It is evident that there may be an inequality assigned to both husband and wife. This inequality affirms the theory that Hollander (2002) states earlier 'the concept of genderinequality', that it is indeed a social construction, which had been imposed to both gender, however only women, usually have to bear all domestic burdens.

Furthermore, Lahiri (1999) showed that Mrs. Das cheats with her husband's friend. This is shown after she experienced great tiredness and depression. In continuation to Mrs. Das's depression, loneliness, and tiredness, Mrs. Das then has affair with her husband's friend. Nevertheless, her affair might happens out of love since she does not really know the man. She just welcomed the man along with his intention to have sex with her, without really wanting to have relation with the man. The affair of Mrs. Das can be read in the following quotation.

She made no protest when the friend touched the small of her back as she was about to make a pot of coffee, then pulled her against his crisp navy suit. He made love to her swiftly, in silence, with an expertise she had never known.

A simple affair which is done out of love, in fact, can influence Mrs. Das in a terrible way. The secret she has to keep about the affair creates another psychological burden. She states at the following quotations that she develops urges to destroy things around her, even 
she states that she wants to throw her children out the window. Lahiri (1999) narrates her depression in a very interesting way by showing that Mrs. Das leaks her secret to an interpreter, whom her family hires for a family picnic. In other words, she tells her secret to a stranger because she cannot endure her psychological burdens anymore. The interpreter whom she tells her story, is a man, named Mr. Kapasi. Lahiri (1999) perhaps wants to ironically imply that keeping dirty secret is a great psychological burden for oneself. How Mrs. Das leaks all her secrets to Mr. Kapasi can be found in the following quotation.

About my secret, and about how terrible it makes me feel. I feel terrible looking at my children, and at Raj, always terrible. I have terrible urges, Mr. Kapasi, to throw things away. One day I had the urge to throw everything I own out the window, the television, the children, everything. Don't you think it's unhealthy?

It means that I'm tired of feeling so terrible all the time. Eight years. I've been in pain eight years. I was hoping you could help me feel better, say the right thing. Suggest some kind of remedy.

There is another notable implication found in how Mrs. Das narrated herself at the previous quotation. It was evident that Mrs. Das is depressed due to woman-oppression. Mrs. Das as a housewife has to take care of her house without getting enough rest, and as a result of that oppression, she gets depressed. Freud (1977) states that depression happens due to loss, either it is a real loss or symbolic loss. Lewinshon (1974) adds that if the person lacks social skills or has complex personality structure, they may have obstacles to make necessary steps to seek new and alternative sources of reinforcement.

Thus, it is evident that Mrs. Das is depressed due to her loss. After she gets married, she starts to lose her female friends and she has a very limited time to socialize with any people aside her family. From Lahiri's short story, Mr. Das, as her husband, is depicted as ignorant husband, means that he does not really try to console his wife emotionally. As a housewife, the main cause of Mrs. Das's depression and her destructive behavior is the loss of social-connection. If a woman only spends her life in house, there is a very little chance that she will develop friendships with people outside her house. Big chance that a woman will loss her social-connection, in the other words, she is alienated socially due to womanoppression. 
Similar case is experienced by Ella Marchmill, as housewife character in Hardy's short story. The short story title is An Imaginative Woman which was published in 1893. It is part of $19^{\text {th }}$ century literature, thus most of woman's role-model is stated clearly in the form of social-concepts and social-limitations which were forcibly intended for woman. Those social-limitations are experiences by the female character named Ella Marchmill. She is a wife of a gun maker. She is a housewife which has another side job as a poet. Through Ella's life, Hardy explicitly describes 'the cardinal virtue' as a concept which dominates woman's life at $19^{\text {th }}$ century. The description is stated at the beginning of the story at the following quotation.

She had never antecedently regarded this occupation of his as any objection to having him for a husband. Indeed, the necessity of getting life-leased at all cost, a cardinal virtue which all good mothers teach, kept her from thinking of it all. She came to some vague conclusions, and since then had kept her heart alive by pitying her proprietor's obtuseness and want of refinement, pitying herself, and letting off her delicate and ethereal emotions in imaginative occupations, daydreams, and night-sighs.

In the natural way of passion under the too practical conditions which civilization has devised for its fruition, her husband's love for her had not survived...

At the previous quotation, Hardy (1893) describes how Ella concludes that she pitied herself and women in general. Possibly this happens because as a woman she realized how coercive 'cardinal virtue' can be. Cardinal virtue is a concept of woman's role-model which dominated England at $19^{\text {th }}$ century. As stated by Barbara Welter in Dimity Convictions: The American Woman in the Nineteenth Century (1976), a "True Woman" was designated as the symbolic keeper of morality and decency of women virtues: Piety, purity, submissiveness, and domesticity. Thus, this concept bound women to her house and especially to be the servant of the men, since submissiveness and domesticity are emphasized as one of virtues.

Ella Marchmill in the story is described as disappointed housewife. She is disappointed that her life as a woman is limited and restricted by civilization's practicalities which do not allow passion and love to flourish within her. The self-pity she experiences as woman, along with her feelings and creativity, shape her as a woman with enhanced imagination. Because of her having a lot of imagination and delicate feelings, she becomes a 
poet. However, she has to disguise herself as man named 'John Ivy'. This happens because women are not appreciated professionally in $19^{\text {th }}$ century. Subconsciously, Ella also knows how society has underestimated, and furthermore, devalued women and their market work in general. Ella's realization of woman-devaluation is shown in the following quotations.

Ella, otherwise "John Ivy,"... had satisfied herself with a sort of reason for doing the contrary in her case; since nobody might believe in her inspiration if they found that the sentiments came from a pushing tradesman's wife, from the mother of three children by a matter-of-fact small-arms manufacturer.

Ella's realization is in agreement with Katz et. all (2005) who states that exploitation may took various forms. Exploitation can be found as rules that prohibited the employment of married women, actions by labor unions concerned with preserving male family wages, and hegemonic cultural ideas that assigned married women to domestic labor while devaluing the kinds of market work they performed, to name three that were particularly important.

Ella's realization toward how women are devalued and underestimated, along with creative imaginative mind, later bring her into new state of life. That is when she becomes obsessed with a poet she never acquainted. The poet name is Robert Trewe, a man whose room is hired for her family-vacation. Ella finds that Trewe's poems describe what she feels and thinks, thus she appreciates him as a genius. Nevertheless, her appreciation is too much and it quickly turns into unhealthy obsession, in which, she even wears some Trewe's outfits for her obsessive amazement. The beginning of Ella's unhealthy obsession can be found in the following quotation.

Possessed of her fantasy, Ella went later in the afternoon, when nobody was in that part of the house, opened the closet, unhitched one of the articles, a mackintosh, and put it on, with the waterproof cap belonging to it. "The mantle of Elijah!" she said. "Would it might inspire me to rival him, glorious genius that he is!"

The consciousness of her weakness beside him made her feel quite sick. Before she had got the things off her the door opened, and her husband entered the room. "What the devil - ", said her husband

From the previous quotation, Ella's husband also implies how unhealthy her obsession by calling her 'the devil'. Even though her husband has displayed negative reaction concerning her obsession, Ella does not try to stop her habits. She even takes Trewe's photograph and treats that photograph in special way. She has the feelings, that even she does 
not know Trewe, that they have same feelings. It must be noted here that Ella and Trewe never meets at all, and Trewe does not even know Ella's existence. Nevertheless, Ella's obsession gets stronger, composted by her rich imagination, and she does not have any clue that her obsession is unhealthy. She even compares Trewe and her husband, even though Trewe does not know her at all. This can be seen in the following quotations.

She gazed long at the portrait she fell into thought, till her eyes filled with tears, and she touched the cardboard with her lips. Then she laughed with a nervous lightness, and wiped her eyes. She thought how wicked she was, a woman having a husband and three children, to let her mind stray to a stranger in this unconscionable manner. No, he was not a stranger! She knew his thoughts and feelings as well as she knew her own; they were, in fact, the self-same thoughts and feelings as hers, which her husband distinctly lacked.

Despite Ella's imagination and obsession, her efforts to meet Trewe directly are always unsuccessful. Thus, she spends most of her time in uncertainties and yearns. She begins to get depressed and starts to hate her children because she feel that they cannot meet her romantic ideal, just like her husband. Her disgust toward her children is stated in the following quotation.

As soon as she could get away she went into the nursery and tried to let off her emotion by unnecessarily kissing the children, till she had a sudden sense of disgust at being reminded how plain-looking they were, like their father.

Ella enters her depression period when she hears the news of Trewe's suicide from newspaper. Trewe's death creates a powerful impact on her, to the point that she gets hysterical mourn. She even blames God and called God as 'jealous', even though, she never meets Trewe at all. Ella's imagination about her relationship with Trewe has exaggerated her reaction then created a severe depression for her. How Ella mourns and enters her depressive psychological state is shown in the quotation below.

Her grief and distraction shook her to pieces; and she lay in this frenzy of sorrow for more than an hour. Broken words came every now and then from her quivering lips: "O, if he had only known of me - known of me - me! . . O, if I had only once met him - only once; and put my hand upon his hot forehead - kissed him - let him know how I loved him - that I would have suffered shame and scorn, would have lived and died, for him! Perhaps it would have saved his dear life! . . . But no - it 
was not allowed! God is a jealous God; and that happiness was not for him and $m e !^{\prime \prime}$

Even after some monts after Trewe's death, Ella does not recover from her depression. When the time for her childbirth comes, she does not raise her spirits. She is still thinking of Trewe's death. She conveys her wish to her husband that she does not want to get over her illness. This means that she implicately wishes her own death. Ella's death really occurs at the end of the story, and it is evident that until the story ends, she does not recover from her depression as told in the following quotation.

Ella seemed to be only too frequently in a sad and listless mood. The time was approaching when she would have to undergo the stress of childbirth for a fourth time, and that apparently did not tend to raise her spirits.

"I don't think I shall get over it this time!" she said one day.

"I am not going to get over my illness this time, " she reiterated. "Something tells me I shan't." This view of things was rather a bad beginning, as it usually is; and, in fact, six weeks later, in the month of May, she was lying in her room, pulseless and bloodless, with hardly strength enough left.

\section{Conclusion}

There is an obvious evident that woman-oppression is constructed by civilization. Hollander (2002) states that gender is a social construction, not something related to biological differences or biological distinction. Gender is a social institution, and thus it is something that members of a society create, maintain and impose. In two short-stories, both housewives characters experience woman-oppression. Although they experience it in different manner, both of them essentially experience the same thing that is 'woman-devaluation', which can be a common occurrence in patriarchy society. The devaluation, restriction, and underestimation of women may lead them into unhealthy habits, such as obsession, and sometimes, destructive depressed behaviors. Both of the housewife characters in two short stories showed that woman-oppression may cause psychological burdens, and if women are also alienated socially, then it may lead to severe prolonged depression. 


\section{REFERENCES}

Abrams, M.H. (1971). A Glossary of Literary Terms. Third Edition. Holt, Rinehart and Winston, Inc. United States.

Cruea, M.S. 2005. "Changing Ideals of Womanhood During the Nineteenth-Century Woman Movement”. General Studies Writing Faculty Publications. Bowling Green State University. ScholarWorks@BGSU. Web. 5 ${ }^{\text {th }}$ February 2016.

Eagleton, T. 1983. Literary Theory. Oxford: Black well Publisher Limited.

Freud, S. (1917). Mourning and melancholia. Standard edition, 14(19), 17.

Scribner. 1987. The complete short stories of Ernest Hemingway. Simon \& Schuster Inc. USA. P. 109-111

Hollander, Jocelyn A. 2002. "Resisting Vulnerability: The Social Reconstruction of Gender in Interaction." Social Problems 49.4: 474-496. JSTOR. Web. $5^{\text {th }}$ February 2016.

Katz et all. 2005. "Women and the Paradox of Inequality in the Twentieth Century". Journal of Social History. Vol 39. Issue 2. pp 65-88. George Mason University Press. Web. 5 February 2016.

Lahiri, J. 1999. Interpreter of Maladies. Houghton Mifflin. United states. Unprint. p 12-29.

Lewinsohn, P. M. (1974). A behavioral approach to depression.

MacKinnon, A.C., 1982. "Feminism, Marxism, Method, and the State: An Agenda for Theory". Signs, Vol. 7, No. 3, Feminist Theory, (Spring, 1982), pp. 515-544. [Not Printed]

Peterson, Linda H. 1992. Wuthering Heights: Emily Bronte. Bedford. United Kingdom. Unprinted.

Potter, J. L. 1967. Element of Literature. The Odyssey Press. United States. Unprinted.

Robert, V.E. 2003. Writing About Literature. Tenth Edition. Pearson Education, New Jersey. p.294-295

Rabb, M.J. 1998. The Short Story and Photography, 1880's-1980's: A Critical Anthology. University of New Mexico Press. Albuquerque. Web. $5^{\text {th }}$ February 2016. p.58-79.

Seligman, M. E. (1973). Fall into helplessness. Psychology today, 7(1), 43-48.

Seligman, M. E. (1974). Depression and learned helplessness. John Wiley \& Sons. 
Wellek, R. and Warren, A. 1977. Theory of Literature. Harcourt Brace Jovanovich Inc. United States of America. Unprinted. 